\title{
THEORETICAL ASPECTS OF STATE REGULATION OF NATIONAL MACROECONOMIC ENVIRONMENT
}

\author{
Yevgen MASLENNIKOV' ${ }^{1}$, Nataliia LENSKA ${ }^{2}$ \\ Odesa I.I. Mechnikov National University, Ukraine
}

\begin{abstract}
The question of the economic role of the state was put up for a long time and until now every state solves this problem in different ways and only for itself, on the basis of the accumulated experience taking into account its customs and traditions. The objective need to include the state in the economic process is determined by such factors as: the need to ensure public reproduction on an extended scale, ensuring the long-term interests of the population, maintaining the balance of socio-economic interests of different population groups in the country, ensuring the unity and integrity of the country's territorial space. For this reason, the purpose of the paper is to examine the main theoretical aspects of state regulation of the economy in historical retrospect and at the present stage of the development of society. Methodology. Methodological and informational basis of the investigation are scientific articles, materials of periodicals, resources of the Internet. To achieve the goal set, the following general scientific and special methods were used: morphological analysis, system and structural-logical analysis, formalization, analogy, comparison and integration, tabular method. Results. As a result of the research, scientific and theoretical grounds for state regulation of national macroeconomic environment were presented; forms and methods of state regulation, programming as a form of perspective state regulation and principles of economic planning were considered in more detail. Practical implications. The considered forms of state regulation are relevant in the current conditions of management and can be applied by states in accordance with the level of economic development. Value/originality. The authors presented innovative forms of state regulation methods, and analyzed their effectiveness.
\end{abstract}

Key words: state regulation, regulated economy, management, national macroeconomic environment, economic development, forms of intervention, programming, planning.

JEL Classification: B300, H100

\section{Introduction}

The objective need for conscious regulation of the entire social economy is not just obvious, its realization has become a fact of the economic life of all developed countries with market economy. The entire experience of state regulation of national macroeconomic environment, the functions of the state in ensuring social and economic stability in society, and scientific and technological progress demonstrate that it is not just a matter of the impact on the course of reproduction that has occurred before, but of a new type of management when the entire public economy is consciously and constantly regulated.

A fundamental conclusion about the need for such regulation was made at the end of the last century. However, if we take a look at the economy of developed capitalist countries, then only in recent decades it has been confirmed by the whole practice of regulating economic life, regardless of the doctrines proclaimed by the proponents of liberalism or Keynesianism.

\section{Evolution of theories of state regulation}

The history of state regulation dates back to the end of the Middle Ages (mid-17th century). The main economic school was the school of mercantilists. It proclaimed active intervention of the state in the economy. Mercantilists argued that the main indicator of the country's wealth is the amount of gold. In this regard, they called for encouraging exports and curbing imports (Didkivska, 2013).

The next stage in the development of ideas about the role of the state is A. Smith's work "An Inquiry into the Nature and Causes of the Wealth of Nations", in which he argued that "the free play of market forces" (the "laissez faire" principle) creates a harmonious arrangement". In accordance with the classical approach, the state must ensure the safety of human life and its property, resolve disputes, in other words, do what the individual either cannot do on his own, or does it inefficiently. In his description of the system of market economy,

\footnotetext{
Corresponding author:

${ }^{1}$ Department of Economics and Management, Odesa I.I. Mechnikov National University.

E-mail: evgenmaslennikov@ukr.net

${ }^{2}$ Department of Economics and Management, Odesa I.I. Mechnikov National University.

E-mail: nlenskaya96@mail.ru
} 
A. Smith argued that ithe main driving force of economic development is the entrepreneur's desire to achieve his private interests, ultimately increasing the welfare of both himself and society as a whole. The main thing was that for all business entities the basic economic freedoms should be guaranteed, namely: freedom to choose the sphere of activity, freedom of competition and freedom of trade.

In the 1930s, after the deepest recession in the US economy, J. Keynes put forward a theory in which he refuted the views of the classics on the role of the state. Keynes's theory can be called "crisis", as he considers the economy in a state of depression. According to his theory, the state should actively interfere with the economy, since the free market lacks mechanisms that would truly ensure the economy's exit from the crisis. The state should influence the market in order to increase demand, since the cause of capitalist crises is the overproduction of goods. Keynes proposed several instruments: a flexible monetary policy, a new fiscal policy (Didkivska, 2013).

Flexible monetary policy allows to step through one of the most serious barriers - inelasticity of wages. This is achieved by changing the amount of money in circulation. With an increase in the money supply, real wages will decrease, which will stimulate investment demand and employment growth.

By the means of fiscal policy, Keynes recommended the state to increase tax rates and finance these unprofitable enterprises at the expense of these funds. This will not only reduce unemployment, but will also relieve social tension.

The main features of the Keynesian regulatory model are:

- the high share of national income, redistributed through the state budget;

- creation of an extensive zone of state entrepreneurship on the basis of the formation of state and mixed enterprises;

- wide use of budgetary and fiscal regulators to stabilize the economic environment, smoothing cyclical fluctuations, maintaining high growth rates and high level of employment.

The Keynesian model could be sustained only under conditions of high growth rates of the economy. However, in the 1970s the conditions for reproduction deteriorated sharply. The law of Phillips was disproved, according to which unemployment and inflation cannot grow simultaneously. The Keynesian ways out of the crisis have only untwisted the inflationary spiral. As a result of crisis, a radical restructuring of the system of state regulation took place and a new, neoconservative model of regulation developed.

The theoretical basis of the neoconservative model was the concept of the neoclassical direction of economic thought. The transformation of the model of state regulation was the rejection of the impact on reproduction through demand, instead it was assumed that indirect measures of influence on supply would be used.

Proponents of the supply economy consider it necessary to recreate the classical mechanism of accumulation and revive the freedom of private entrepreneurship. Economic growth is seen as a function of capital accumulation. It is carried out through two sources: own funds, that is the capitalization of part of the profit, and borrowed funds (loans). Therefore, in accordance with this theory, the state must provide conditions for the process of capital accumulation and increase of labor productivity.

The main barriers on this way are high taxes and inflation. High taxes limit the growth of investment, and inflation increases the cost of credit and thus makes it difficult to use borrowed funds for accumulation. Therefore, neoconservatives proposed the implementation of anti-inflationary measures based on recommendations of monetarists and granting tax benefits to entrepreneurs (Didkivska, 2013).

Reduction of tax rates will reduce the revenues of the state budget, increase its deficit, which will complicate the fight against inflation. This means that the next steps will be: reduction of government expenditure, refusal to use the budget to support demand and implementation of large-scale social programs (this may include the policy of privatization of state property).

The next set of measures is the implementation of the policy of deregulation. This means elimination of regulations on prices and wages, liberalization (mitigation) of antitrust legislation, deregulation of the labor market.

Thus, the historical experience of the functioning of a consciously regulated type of social economy shows that its formation takes place within the framework of global trends in the change of types of social economy and appears in diverse forms.

\section{Functions of state regulation}

The stable functioning of market economy assumes that the state realizes its economic role by means of a corrective, regulating distribution processes, stabilization function and the function of creating legal conditions for economic activity (Sokolovska, 2016).

Realizing the corrective function, the state carries out two main tasks:

- adjusts the results of market processes; - provides the production of "public goods".

Another important function of the state is the regulation of distribution processes occurring in the market system. In this case, the aim of state intervention is, as a rule, to reduce the difference in income and property between individual entities, which is determined by the operation of the market mechanism. 
Stabilization function. Instruments of fiscal policy are actively used by the modern state to ensure:

- conjunctural stability;

- high level of employment;

- counteraction to inflationary processes.

This policy has received the title of "fiscal" in the Western economic literature and comes down to the following three basic principles:

- if there is underemployment due to insufficiently high demand, then the latter should be increased by appropriate changes in budget expenditures and incomes (expansive budget policy);

- if there is an increase in the price level (inflation), then government revenues and expenditures should be applied in such a way that the result would be a decrease in aggregate demand (counteractive budget policy);

- if there is full employment with a stable price level, then public finance should be used in such a way that aggregate demand would remain unchanged (neutral budget policy).

\section{Forms of state regulation of the economy}

In the process of creating general legal conditions for economic activity, the state determines the forms and property rights, the conditions for concluding contracts and business agreements, the organizational and legal framework for the operation of enterprises, the rules for the operation of financial and credit institutions, and others. Besides, social regulation is one the most important directions: legislative regulation of the minimum wage, working conditions at enterprises, social insurance and social security issues (guaranteed minimum, social assistance to the poor), relations within the framework of collective agreements.

Considering the form as an external expression of the content of state regulation, it is possible to single out such basic forms as law-making, support, stimulation, legalization, regulation and coordination. The essence of these forms, expressed through the activities of public authorities, is presented in Table 1.

Table 1

Main forms of state regulation and their essence

\begin{tabular}{|c|l|l|}
\hline No. & $\begin{array}{c}\text { Form of state } \\
\text { regulation }\end{array}$ & $\begin{array}{l}\text { The actions of public authorities in the } \\
\text { implementation of regulatory forms }\end{array}$ \\
\hline 1 & Law-making & $\begin{array}{l}\text { Development of state laws, local laws and } \\
\text { other regulatory legal acts }\end{array}$ \\
\hline 2 & Support & Assistance to business entities \\
\hline 3 & Stimulation & $\begin{array}{l}\text { Incentive activities in the involvement of } \\
\text { various subjects into the economy }\end{array}$ \\
\hline 4 & Legalization & $\begin{array}{l}\text { Granting permission for any activity to } \\
\text { organizations, enterprises, institutions } \\
\text { and individual entrepreneurs }\end{array}$ \\
\hline 5 & Regulation & $\begin{array}{l}\text { Determination of the rules, defining an } \\
\text { order of any activity }\end{array}$ \\
\hline 6 & Coordination & $\begin{array}{l}\text { Organization of interaction, coordination } \\
\text { of actions of various subjects in solving } \\
\text { common problems }\end{array}$ \\
\hline
\end{tabular}

State regulation is the process of state orientation of the reproduction of social capital, organized by a monopolized competitive-market mechanism in the direction of the envisaged variant of movement and development (Malynovskyi, 2010). This definition does not exclude that at some points the state impact on the economy can be very tough, quite directive, and sometimes close, in fact, to management.

Let us point out the main forms of state intervention in the economy. First of all, it is important to distinguish the main forms: direct intervention, indirect intervention and economic programming.

Direct intervention. In all industrialized countries there is a more or less significant public sector of the economy. Its dimensions can serve as a criterion for the economic role of the state, although this criterion is not absolute. The state has the capital in a variety of forms, provides loans, takes equity participation, is the owner of enterprises. This makes the state a co-owner of a part of the social capital.

Direct intervention of the state is the adoption of legislative acts designed to streamline and develop relations between all elements of the market system. Examples of state regulation of the economy through the development of legislative acts are extremely diverse, for example, the adoption of the Civil Code, the Tax Code, laws against restrictive business practices (antitrust laws).

Indirect intervention assumes the implementation of state regulation by the use of main instruments of state economic policy, which are fiscal and monetary policy.

Economic programming is the highest form of state intervention in the process of reproduction, which is carried out on the basis of agreements between the state and monopolies. It includes: compiling forecasts for the development of the economy for the forthcoming period; the definition of the most common goals of economic policy for the entire economy as a whole; coordination of the entire state apparatus in the implementation of the planned program (Malynovskyi, 2010).

These directions of the state policy are closely connected with each other.

\section{Main methods of regulation}

Considering the essence of state regulation of the economy, it is necessary to consider the problem of regularity.

Achievement of regularity presupposes the operation of a certain mechanism. First of all, the state should have some tangible and intangible resources of regulation that are means that can be used to implement these goals. Among them there are public finances, the public sector of the economy, legislative law and a possibility of collecting and processing information. 
The practical and purposeful application of these means requires certain tools - methods of regulation. These methods can be classified as follows:

- management of state property;

- methods of economic influence - government consumption, social spending, fiscal policy, taxation, - regulation of monetary circulation and granting of credits, financing, financial selective regulation;

- methods of administrative and economic influence

- control over the credit system, income, pricing, contracts, "built-in stabilizers";

- methods of administrative influence carried out by introducing legislative or administrative restrictions that do not affect the movement of cost factors;

- methods of information influence, as well as state economic legislation and inspection (Hrynova, 2015).

\section{Programming as an innovative form of state regulation}

Programming is one of the concrete forms, first of all, oflong-term regulation, and therefore it can be defined as the process of organizing of production development by the state by means of regulatory and complex influence on its structure in accordance with the envisaged option of social and economic development and economic strategy.

The programming of the economy is understood as the scheduling of an activity plan in which, in a certain sequence, the main economic objectives and goals set by the government are stated, and actions for economic development are defined (Fig. 1).

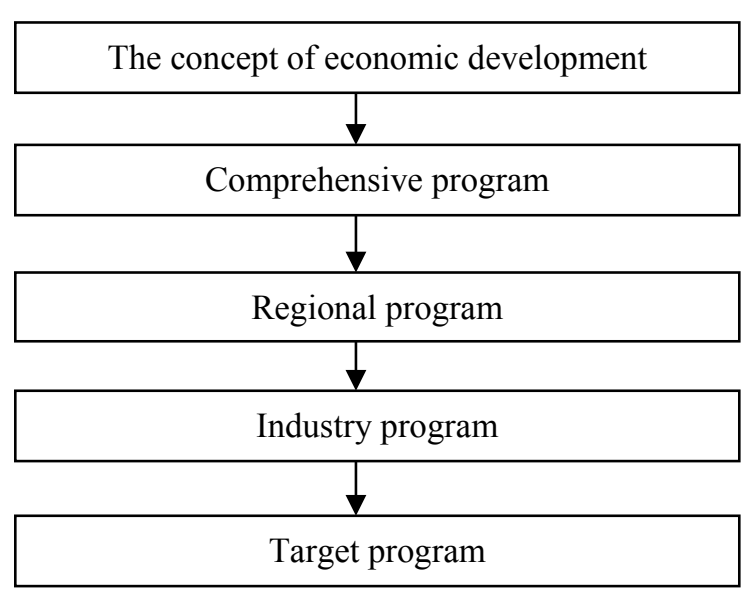

Fig. 1. Main stages of programming

Being the most developed and generalizing form of regulation, programming does not shun the current influence on the economy. Programs cannot provide the current regulation itself, but it is possible to outline a concept of economic policy, including tactical moments. Programs may contain even some quantitative benchmarks for market regulation. We must not forget that the current regulation serves, anyway, the implementation of the prospective.
The mixed form of regulation, known under the title of stabilization plans, adjoins programming, by means of which both perspective and current tasks are solved to maintain the balance of production, its more even dynamics. At its basis, stabilization plans belong to the market regulation (Kruhliak, 2014).

But to the extent that they serve to combat structural imbalances, they can be considered both as a form of structural regulation, and, consequently, as an element of the programming system. It should be noted that only some private programs and stabilization plans are subject to mandatory implementation, but their implementation can be stopped at any time. As for medium-term plans and economic budgets, they are recommendatory in nature and their implementation is not strictly mandatory.

\section{Application of the planning mechanism in the practice of state regulation}

Planning is the most important tool of the economic mechanism. Planning is a concrete form of realizing the objective need for coordinated, balanced development of all sectors and regions, all spheres of social reproduction.

The need for planning on the scale of the entire economic system increases with the increase in the level of socialization of production and labor, the formation of a unified national economic complex, in which production, distribution, exchange and consumption are organically linked throughout the country.

Planning is a form of using the entire system of economiclaws. Planning allows to develop harmoniously all sectors of the economy, to use the material, labor and financial resources of the country rationally, to establish optimal inter-industry and intra-industry proportions, to locating the productive forces rationally in order to achieve greater economic efficiency of social production (Kondratov, 2014).

In the planning process, the interests of social stratum and groups (workers in different spheres and sectors, children, youth, older people), as well as regional and federal features are taken into account and interrelated. Objectivity belongs to the key principles of planning. To realize the principle of objectivity means to improve the planned activity of central economic bodies, to direct the entire planned work.

In planning, coordination of national, cross-sectoral, sectoral and regional approaches is needed. The country's economy is developing a system of plans. It includes a unified plan for economic and social development of the country, sectoral and regional plans.

Any plan includes the following components:

- goals and objectives, which, eventually, are the satisfaction of social needs;

- ways and means to achieve the goals;

- resources needed to solve planned tasks; 
- proportions, ensuring a balance in the development of the economy.

A component of the planning activity is the practical work on its implementation and monitoring the implementation of the plan. The development of the plan is preceded by the stage of forecasting, when conditions, paths and tasks of the future development of the economy are revealed (Fig. 2).

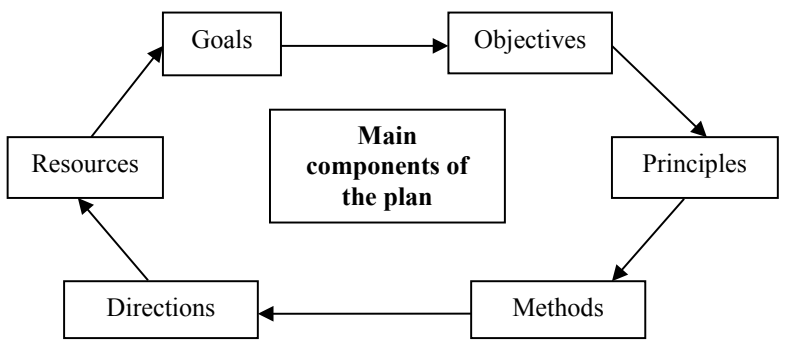

Fig. 2. Main components of the plan

Planning is based on the principles of objectivity, continuity, scientific character, political approach, a combination of sectoral and territorial.

The principle of scientific validity of regularities of the development of material and technical base, of necessary structural changes and trends in economic transformations provides the basis for identifying the urgent needs, their scales, ways and the real possibilities of satisfaction.

The principle of a political approach to the formation of planned installations is aimed at real transformation of economic planning into a factor that ensures the achievement of the fundamental goals of society. Economic policy, being a reflection of progressive changes, takes precedence over a purely economic approach in planning.

The principle of the targeted approach in planning is designed to ensure a meaningful unity of the plans made. It reflects, on the one hand, the multifaceted nature, the interdependence of economic processes, and on the other hand, their subordination, ultimately, to one common strategic goal.
The principle of continuity of planning is aimed to ensure the interdependence of plans in time. It reflects the continuity of the economic processes themselves, expressing the progressive development of the economy. It is the temporary continuity of economic processes that makes it necessary to develop a system of plans that ensure the continuity of planning.

The principle of combining sectoral and territorial planning reflects the need to ensure the integrated development of all regions of the country, the use of the funds of enterprises in this process, located in a particular region. The value of the optimal combination of the sectoral and territorial aspects of the plan is substantially increasing in modern conditions.

One of the most important tasks of planning is to ensure the balance and constant support of proportionality in the development of the economy. This determines the special importance of the balance method in planning.

\section{Conclusions}

The conducted analysis has shown that, at different stages in the development of economic thought and the world economy, the problem of state regulation was mainly solved empirically and came down to a research of several aspects: analyzing the object of state regulation, determining the optimal combination of regulatory instruments, determining the role of the state in the economic system, searching effective way of distribution the powers between state institutions.

When carrying out economic policy it is important to remember that both the state and the market are the great achievements of civilization. The market cannot function normally without the state that sets and maintains the "rules of the game" in the market economy. But there are also objective limits of state intervention. The market and the state are two powerful forces that do not oppose each other, but complement each other in the course of economic development.

\section{References:}

Hrynova V.M. (2015). Derzhavne rehuliuvannia ekonomiky. - Kyiv: Znannia, 398 p.

Didkivska L.I. (2013). Derzhavne rehuliuvannia ekonomiky. - Kyiv: Znannia, 213 p.

Malynovskyi V.I. (2010). Derzhavne upravlinnia. - Kyiv: Atika, 576 p.

Maslennikov Y., Balan O., Selivanova N. (2017). Identifying areas and components of the management decisions for small industrial enterprises the second and third group of simplified tax system. - Marketynh i menedzhment innovatsii. № 3, p. 257-266.

Maslennikov Y.I., Yakubovskyi S.O., Beliakova V.V. (2017). Pryntsypy derzhavnoho rehuliuvannia natsionalnoi ekonomiky v umovakh hlobalizatsii. - Visnyk Odeskoho natsionalnoho universytetu. Seriia: Ekonomika. № 2(55), p. 65-69.

Kondratov O.M. (2014). Suchasni tendentsii rozvytku derzhavnoho rehuliuvannia ekonomiky v Ukraini. Ekonomika ta derzhava. №3, p. 61-65.

Kruhliak A.M. (2014). Rol derzhavy v pidvyshchenni efektyvnosti antykryzovoho upravlinnia ekonomikoiu. Derzhava ta rehiony. №6, p. 98-109. 
Poberezhets O.V. (2016). Teoretyko-metodolohichni ta praktychni zasady doslidzhennia systemy upravlinnia rezultatamy diialnosti promyslovoho. - Kherson: Hrin D.S., 500 p.

Sokolovska A.M. (2016). Ekonomichna funktsiia derzhavy ta osoblyvosti yii vykonannia v Ukraini. - Ekonomika Ukrainy. №3, p. 33-37.

\section{ЕвГенИЙ МАСЛЕННИКОВ, НаталИЯ ЛЕНСКАЯ \\ ТЕОРЕТИЧЕСКИЕ АСПЕКТЫ ГОСУДАРСТВЕННОГО РЕГУЛИРОВАНИЯ НАЦИОНАЛЬНОЙ МАКРОЭКОНОМИЧЕСКОЙ СРЕДЫ}

Аннотация. Вопрос об экономической роли государства был поставлен еще давно и до сих пор каждое государство решает эту проблему по-разному и только для себя, на основе накопленного опыта с учетом своих обычаев и традиций. Объективная необходимость включения государства в экономический процесс определяется такими факторами, как: необходимость обеспечения общественного воспроизводства в расширенном масштабе, обеспечение долговременности интересов населения, поддержание баланса социально-экономических интересов различных групп населения в стране, обеспечение единства и целостности территориального пространства страны. По этой причине челью работы является рассмотрение основных теоретических аспектов государственного регулирования экономики в исторической ретроспективе и на современном этапе развития общества. Методология. Методологической и информационной основой работы являются научные статьи, материалы периодических изданий, ресурсы сети Интернет. Для достижения поставленной цели были использованы следующие общенаучные и специальные методы: морфологического анализа, системного и структурно-логического анализа, формализации, метод аналогии, сравнения и интегрирования, табличный метод. Результаты. В результате исследования были представлены научно-теоретические обоснования государственного регулирования рыночной экономики; более подробно рассмотрены формы и методы государственного регулирования, программирование как форма перспективного государственного регулирования и принципы планирования экономики. Практическое применение. Рассмотренные формы государственного регулирования актуальны в современных условиях хозяйствования и могут быть применены государствами в соответствии с уровнем экономического развития. Ценность/оригинальность. Авторами были представлены инновационные формы методы государственного регулирования, и проанализирована их эффективность. 